\title{
AN EVALUATION OF CLASSLESS HEALTH SERVICES FOR POOR FAMILIES (GAKIN) IN WATES, KULON PROGO REGENCY
}

\author{
Sakir $^{1}$, Muhammad Eko Atmojo ${ }^{2}$, Asmarawati Handoyo ${ }^{3}$ \\ ${ }^{1}$ Lecturer of Govermental Science, Universitas Muhammadiyah Yogyakarta \\ ${ }^{2}$ Lecturer of Govermental Science, Universitas Muhammadiyah Yogyakarta \\ ${ }^{3}$ Student of Doctoral Program, National Cheng Kung University \\ 1'mas_sakir@gmail.com; 2atmojoeko91@gmail.com; 33asmarawatihandoyo@yahoo.com \\ DOI: https://doi.org/10.18196/jgpp.5298
}

Article Info

Article history:

Received 05 Jun 2018

Revised 14 Jun 2018

Accepted 02 Jul 2018

\section{Keywords:}

Evaluation, Health service, Poor families (Gakin).

\section{ABSTRACT}

One of the important principles of public service delivery is that service for its people, meaning that public services contain the principles of equity which all societies are entitled to the same public service without discriminatory treatment. Service is given regardless of status, rank, class of all society. It can not be denied, however, that some sectors of public services still impose differentiation of services through the creation of classes, one of which is hospital service. For the sake of the realization of excellent service and contains the principles of fair/equity Wates hospital apply a new innovation of inpatient hospital services for poor families (Gakin). The existence of classless innovation for the poor families will be able to create a service that contains the principles of justice/equity, as of that people get the same public service and there is no discriminatory to the public service. The Implementation of a classless hospital for the poor is relatively running smoothly, indicated in the absence of conditions that make it difficult for patients to register. Every society that uses health insurance cards is entitled to the same service and there is no differences treatment. This is done in Wates hospital in the implementation of services without classes for the poor families.

\section{ABSTRAK}

Salah satu prinsip penting dari penyelenggaraan pelayanan publik adalah pelayanan bagi masyarakatnya, artinya pelayanan publik memuat prinsip-prinsip keadilan/equity dimana semua masyarakat berhak atas pelayanan publik yang sama tanpa adanya perlakukan diskriminatif. Pelayanan diberikan tanpa memandang status, pangkat, golongan dari semua masyarakat. 
Namun tidak dapat dipungkiri beberapa sektor pelayanan publik masih memberlakukan pembedaan pelayanan melalui penciptaan kelas, salah satunya adalah pelayanan di rumah sakit. Demi terwujudnya pelayanan prima dan memuat prinsip adil/equity RSUD Wates menerapkan inovasi baru yaitu pelayanan rawat inap tanpa kelas bagi keluarga miskin (Gakin). Adanya inovasi tanpa kelas bagi masyarakat miskin nantinya bisa menciptakan pelayanan yang memuat prinsip-prinsip keadilan/equity, sehingga masyarakat mendapatkan pelayanan public yang sama dan tidak ada kata diskriminatif terhadap pelayanan publik. Pelaksanaan rumah sakit tanpa kelas bagi masyarakat miskin relative berjalan dengan lancar, hal ini ditunjukkan dengan tidak adanya syarat yang menyulitkan pasien untuk mendaftarkan diri. Setiap masyarakat yang menggunakan kartu jaminan kesehatan berhak mendapatkan pelayanan yang sama dan tidak ada perbedaan. Hal inilah yang dilakukan di RSUD Wates dalam pelaksanaan pelayanan tanpa kelas bagi masyarakat miskin.

\section{INTRODUCTION}

One of the main functions of state existence beside to development and implementation of protection function is the obligation to provide public services in the form of goods and services in accordance with the needs and expectations of the community. Through public services, the needs of the community, especially the basic needs could be fulfilled and the various problems that arise in society can be resolved.

One of the important principles of public services delivery is the service for society, that is mean the public services contain the principles of equity in which all peoples are entitled to the same public service without discriminatory treatment. Service is given regardless of status, rank, class of all society. It can not be denied, 
however, that some sectors of public services still impose differentiation of services through the creation of classes. Things like this have even been considered common. In other words, the quality of certain services can be perceived according to the economic capabilities of the community. One public service that is commonly known to classify classes is inpatient services in hospitals, which generally have several types of inpatient rooms that apply different facilities at a storied cost. Classes that are created include Class III, Class II, Class I, VIP, and VVIP, although they have different facilities but these classes are claimed to have the same service.

The political developments taking place in Indonesia have brought a crucial shift to the quality of public services in Indonesia. Since the reforms over the last two decades, there has been a spirit of decentralization in governance in each regions, including decentralization of public service delivery. The decentralization of public services is followed by the spirit of the region to develop effective and efficient public services, one of them is by developing public service innovations.

Yogyakarta province is one of the areas that develops many innovations of public services in Indonesia, including innovations in governance, education, economic strengthening, ease of licensing, also innovation in the field of health. As implemented Kulonprogo District, one of the districts located in Yogyakarta. Since 2012, RSUD (Regional General Hospital) Wates Kulonprogo Regency has 
212 implemented innovation in the form of inpatient hospital services for poor families (Gakin). Backgrounded by Universal Coverage principle applied by Kulonprogo Regent, Hasto Wardoyo, Kulonprog Government is trying to provide health service for all Kulonprogo community without exception through the implementation of Jamkesmas, Jamkesos and Jamkesda health insurance. Through the provision of these three types of insurance, poor people can feel Class III in hospital services at local government hospitals for free.

The enforcement of these various health insurance resulted in the increasing number of poor families visits to various health centers, especially Wates Kulonprogo Hospital for inpatient care. In 2011, Gakin's (Poor families) visit to RSUD Wates Kulonprogo was around $39.60 \%$, increasing to $43.43 \%$ in 2012 , and increasing in 2013 to $56.35 \%$ (http://indonesiaberinovasi.com). The increasing number of Gakin patients who are inpatient is not directly proportional to the capacity of the third-class residency room owned by RSUD Wates Kulonprogo. To overcome these problems, RSUD Wates Kulonprogo through Decree Director of Waton Kulonprogo Public Hospital. 188/231.1/RS/IV/2012 implements a classless service policy for Gakin that if class III rooms are not available then Gakin patients will still be served by occupying existing wards both in class II, class I, even in the VIP room by enacting the fixed tariff is class III tariff as stipulated in various guarantees granted to the poor families (Menpan: 2014). Through this classless inpatient service, it is 
expected that all people in particular can be served well without exception.

The existence of non-class health services is expected to help overcome various health problems that are still bad in Kulonprogo District such as high infant and under-five mortality rate (AKB), maternal mortality rate (AKI), Malaria infection cases, and various other health problems. Based on Health Profile Kulonprogo Year 2011, AKB Kulonprogo fairly high and has a tendency to increase every year. In 2010, there were $9.8 \mathrm{AKB}$ per 1000 live births $(9.8 / 1000 \mathrm{KH})$, increasing in 2011 to $12.8 / 1000 \mathrm{KH}$, and slightly decreasing in 2012 at $12.1 / 1000 \mathrm{KH}$. The increasing trend of AKB cases is also followed by the increasing trend of AKI cases in Kulonprogo District. In 2010, there were 73.8 AKI per 100,000 live births $(73.8 / 100,000 \mathrm{KH})$, this figure rose sharply in 2011 by $105.2 / 100,000 \mathrm{KH}$, and steadily increased in 2013 by $131.53 / 100,000 \mathrm{KH}$ after earlier dropping to $52.6 / 100,000 \mathrm{KH}$ in 2012. Increasing the number of Malaria infections is not less bad, in 2010 there were only 32 cases of malarial infection, but increased sharply in 2011 as many as 157 cases, and continues to increase in the year 2012 as many as 237 cases in 2012 (http://www.depkes.go.id).

Until now, hospitality service innovation without class hospitals Wates Kulonprogo has been running for more than four years. During that time there have also been many health services 
24. provided including non-class hospitalization for patients with health problems as previously mentioned. Therefore, this research will focus on evaluating the implementation of the classless health service program that is being held by Wates, Kulonprogo regency for poor families.

\section{Literature Review}

An Evaluation is the final stage often done by agencies and organizations to see its performance at one period. Implementation of evaluation is helpful in making policy and policy implementation, with the evaluation of the information will be easy to obtain and the problems that exist in the implementation of the policy can be implemented immediately. Darwin in Nurharjadmo (2008) policy evaluation is basically a process for assessing the extent to which a policy is fruitful by comparing the results obtained with a defined policy objective or goal. Evaluation is an assessment of a problem that generally points to the good of the problem. In relation to a program usually evaluation is done in order to measure the effect of a program in achieving the goals set Hanafi and Guntur in Nurharjadmo (2008).

In principle the type of policy evaluation varies greatly depending on the objectives and levels to be achieved. In terms of evaluation time, there are those classifying into policy preventive and 
summative policy evaluations. Implementation begins at the stage of programming. The way of programming, according to Mazmanian and Sabatier in Kuncoro (2006), is to follow the following steps: (1) identify problems to intervene, (2) define the objectives to be achieved and (3) design the structure of the implementation process.

Meanwhile, according to Simpiagel in Susanti (2009), to create a good health service, there are four dimensions of public services that are used, among others. There are evelectivity, security (minimum risk for patient), cost (minimum), and patient satisfaction. Jacobalis in Susanti (2009) also stated that the quality of health services can be seen from 2 approaches such as:

a) Public healt approach that involves the wide range of health care system and public health status in a country which is shown, among others, through morbidity rate, disability rate, physical and mental development of society in general and so forth,

b) The istitusional/individual approach; the quality of health services is one of the products of the facility's resources and activities against individuals. In order to measure a service it is necessary to provide guidance that is deemed relevant to aspects that have a role to play in the production of such services, differentiated by indicators, criteria and standards.

\section{Research Method}


24. This research uses qualitative approach. Qualitative research is a study that intends to understand the phenomenon of what the subject of research is experiencing holistically and by way of description in the form of words and language, in a natural special context by utilizing various natural methods (Moleong, 2012). Qualitative research has the following characteristics: (1) research data obtained directly from the field, and not from laboratory or controlled research; (2) extracting data is done naturally, making visits to the subject's natural situations; and (3) to gain new meaning in the form of answer categories, researchers must develop a dialogical situation as a scientific situation (Salim, 2006). This research will be conducted at Wates Hospital, Kulon Progo Regency of Yogyakarta Special Province Region. The Data collection techniques in this study is using non-participatory observation, interviews, and documentation. While the data analyst using Miles and Huberman (2014) said there are 3 kinds of interactive data model analyst that can be used, namely; (a) data reduction; (b) the presentation of data; (c) draw conclusions/verifications.

\section{Finding and Discussion}

One of the important principles of public service delivery is the service for its people, it means that public services contain the principles of equity in which all societies are entitled to the same public service without discriminatory treatment. Service is given 
regardless of status, rank, class of all society. It can not be denied, however, that some sectors of public services still impose differentiation of services through the creation of classes. Things like this have even been considered common. In other words, the quality of certain services can be enjoyed according to the economic capabilities of the community. One public service that is commonly known to classify classes is inpatient services in hospitals, which generally have several types of inpatient rooms that apply different facilities at a storied cost. Classes that are created include Class III, Class II, Class I, VIP, and VVIP, although they have different facilities but these classes are claimed to have the same service.

One of the real manifestation to run the excellent public service and contains the principle of fairness/equity in Special Region of Yogyakarta (DIY) especially in Kulonprogo Regency is by applying innovation of health service without class at Wates Hospital. Since 2012, RSUD (Regional General Hospital) Wates Kulonprogo Regency has implemented innovation in the form of inpatient hospital services for poor families. The existence of non-class health services is expected to help overcome various health problems that are still bad in Kulonprogo Regency such as high infant and under-five mortality rate $(\mathrm{AKB})$, maternal mortality rate (AKI), Malaria infection case, and various other health problems.

\section{a. Making Classless Hospital Policy}


The up coming of a classless hospital policy at Wates Hospital together with the presence of the Jamkesmas policy (Community Health Insurance) rolled out by the central government. The presence of Jamkesmas has increased the ability of the community in accessing health services in various health service centers both health centers and hospitals. The community is no longer worried about immediately having a check-up if they encounter health problems.

Increased accessibility of the community to health services resulted in increased number of visits to hospitals, especially for inpatient care. Unfortunately, the increased accessibility of the community to health services is not directly proportional to the availability of inpatient rooms, especially for the lower classes. Therefore, there are often cases where hospitals often refuse the presence of sick people to be hospitalized for reasons of lack of treatment rooms that are appropriate for the class that is the right of prospective patients.

This phenomenon which is considered not in accordance with human values and health code of ethics is encouraging the director of Wates Hospital to innovate health services in the form of Hospitals without Classes. The policy of a classless hospital implemented by Wates hospital basically does not mean eliminating class classification as it has been known for class III, II, I, VIP, or VVIP, but provides any available classroom to patients in need of inpatient but classes that are their rights are not available. The aim of 
giving a classless room is only temporary, in other words if the room that has the right is already available, the patient who is being classed or demoted must return to the class in accordance with his rights. For example, there are poor families with hospitalization rights in class III but because it class is full, they can be hospitalized in class II/I/ even VIP class. However, if during the course of the treatment there is an empty class III room then the patient explained to be transferred to class III as the original rights. The essence of the policy of the hospital without classless is to ensure that the Kulonprogo community in need of hospital care remains underserved and nobody is abandoned.

At the beginning of the implementation of the Jamkesmas era rather than burdening the hospital, the implementation of a classless hospital in turn increases the benefits for hospitals Wates. This is because the government's Jamkesmas program is implemented through a package system, meaning that government payments to the hospital are calculated per patient, whatever inpatient classes the patient lives in and whatever the length of stay of the hospitalization, the price paid by the government is the same for each patient. Therefore Wates District Hospital has additional courage to apply this classless hospital policy especially in accepting gakin patients. With the increasing number of patients, there has also been an increase in the transfer of government health budgets to hospitals.

At least the Wates Regional Hospital implemented three strategic steps to increase the profit and sustainability of the classless 
250 hospital program, namely, first, through the addition of 24 room class III wards so that more and more gakin patients could obtain health services. The second reduces the doctor's service fees. The amount of medical service to the doctor according to the Jamkesmas policy can be given to physicians as high as $44 \%$. The medical services provided by Wates Hospital to doctors in applying hospitals without class is $34 \%$, so the difference of $10 \%$ can be an advantage for hospitals to carry out hospitals without classes, and thirdly through efforts to shorten the number of days of stay for each patient. by enacting patent drugs for patients.

Through the research, Wates Hospital proves that the use of patent medicines will speed up recovery for patients, which means it also provides increased benefits for hospitals. The sooner the patient recovers, the more empty space can be recharged by the new patient. In other words, the more number of patients that can be handled the greater the profit received from central and local government health funds.

The application of classless hospitals in addition to increasing hospital profits has also improved the quality of hospitals in Wates. Before implementing a classless policy Wates Hospital is a type C hospital where only limited services are provided to four specialist services such as internal medicine, surgery, child health, midwifery and mere contents. With the adoption of hospital policy without classrooms Wates Hospital get increased level to hospital with type B 
is a hospital with a broader specialist services with the level of disease complaints that require more seriousness to be addressed. So, the policy of hospital without class in Wates can provide services for gakin community with various complaints of serious illness which require maximal maintenance.

The implementation of a classless hospital on the other hand also raises a cynical manner for patients with basic rights in class II/I/ or VIP. Through self-paid costs in the hope of obtaining better accommodation, self-sufficiency patients are faced with the reality that those who do not pay independently also get the opportunity to enjoy the same accommodation as those who pay independently. As a result, cynicism arises from independent patients. In other words, the existence of a classless hospital as an attempt to create equal opportunities for every society in hospital services has given rise to jealousy for self-sufficient patients who generally come from middle and upper society.

The classless hospital policy implemented by Wates Hospital is not without constraints. Changes to the health insurance policy at the national level through the BPJS program (Soaial Guarantee Board) influence the commitment to implement the internal classless policy at Wates Hospital BPJS programs implemented since 2014 have imposed a system of health premiums for all Indonesian people without exception. The amount of premium paid determines the class of health services that can be enjoyed. As for the community of 
252 the gakin group, then the premium payment is borne by the government with the right of service in class III.

Since it was implemented in 2012 through the Jamkesmas program, the implementation of a classless policy does not burden the Wates Regional General Hospital, on the contrary it provides benefits from the increasing number of patients living in inpatient rooms because the amount of central government transfers is calculated per patient regardless of class. However, since the BPJS policy was enacted, the Wates Regional Hospital claimed to have experienced a decrease in profits due to the central government transfer since the BPJS was enacted based on the rights held by the patient. This means that when the patient is explained to a higher class there is a difference in income from government transfers with the costs incurred on the care of a patient described.

Even though, Wates Hospital continues to carry out classless policies today as when Jamkesmas was still in effect, with the consideration that the implementation of BPJS so far did not make the Wates Hospital suffer losses only the amount of revenue from the government was reduced compared to before. Although the amount of income received is reduced this does not make hospital operations stop, but hospital operations can still run properly. Nevertheless, seeing the trend of profit continues to decrease with the enactment of BPJS while on the other hand the number of gakin patients continues to increase. Wates hospital party assumed that since the 
enactment of BPJS, hospital policy without class is considered to be no longer relevant. Therefore, the Wates Hospital also intends to consider the sustainability of the classless hospital in Wates to continue in the future.

\section{b. Consequences of Hospital Policies Without Classes for Poor Families}

Kulonprogo Regency Government issued public policy innovations in the health sector, one of which was innovation about classless hospitals for poor families. The implementation of this policy aims to reduce health problems both reducing infant mortality and maternal mortality rates in Kulonprogo Regency. The policies that have been implemented from 2012 have a positive impact on the people of Kulonprogo. The policy that has been issued by the Kulonrogo Regency Government has consequences for the government and for the community.

The policy consequences that often arise from the community are related to the assessment of community satisfaction with the policies issued by the government. The community will assess a policy very objectively, but there are several factors that must be met by the government such as policy socialization and so forth. Socialization is very important for the community and the government, especially if there is a new policy. With the socialization, the community will assess a policy very objectively. Therefore the process of socialization 
254 is very important to succeed in a new policy, especially the policy of classless hospitals for poor families.

The socialization of hospital policy without class is not evenly distributed to the people in Kulonprogo Regency. Which are some of the general public who seek treatment at Wates Hospital not yet know much about the policy of classless hospitals in Kulonprogo Regency so that the community does not get detailed information about the policy. So far, people who seek treatment at Wates Hospital only follow the existing rules so that the community does not know if the patient's room is full, there will be an empty space in accordance with the class and the class above.

In addition, which relates to non-grade hospitals for poor families, there are still some things that are not known by the community, such as information about hospital services without classes. Indeed, most people have not received information related to classless hospitals in Wates Hospital. With the uneven data of neighboring class hospitals, most of the community only follow the existing procedures both in terms of service, procedures and stages to obtain non-class service in hospitals. Wates community is only asked to follow the flow. There is no detailed and detailed explanation for the community related to non-class hospitalization service in Wates Hospital. Although the absence of a detailed explanation or socialization of classless hospitals for the community does not mean that Kulonprogo community does not get good service. Every 
community is very easy to get classless inpatient services at Wates Hospital, by simply completing the predetermined requirements which are photocopy of Identity card (KTP) and family card (KK). There is no difficulty experienced by patients when enrolling as a non-class hospitalized patient in Wates Hospital.

The majority of the Kulonprogo people know classless hospital information through relatives or after becoming patients at Wates Hospital. This classless hospital applies to all patients in Wates Hospital. As for information on the procedure of class transfer will be explained when the patient is placed in an inappropriate class such as the patient is placed in class II should be in accordance with the patient's BPSJ card is in the class III. With this explanation the majority of the community will accept with a graceful chest if one day transferred back to the appropriate class. The existence of clarity of information about the hospital without classes is very helpful for the community, so people are not confused when there is movement of the room.

The clarity of information about hospitals without class is not only about clarity of room information but clarity about costs is also very important for the community. With the clarity of the costs used by the patients, the community is not so worried, especially for patients who are supposed to get grade 3 but are transferred to class 2 or VIP. Because if there is no explanation there are a number of things that the community feared, he said, is the addition of costs if 
256 the class/room is not in accordance with the guarantee card. Therefore, there needs to be an explanation of the costs to be incurred by the community. In addition there is an explanation of the costs then there needs to be an explanation of the status of space used by patients, so that patients can receive the consequences if they are transferred back to the room in accordance with the health insurance card.

The details of the cost of a classless hospital is very helpful for people who are treated at Wates Hospital. This is in accordance with the existing reality where the patient will not be charged additional fees if the class occupied is not in accordance with the guarantee card. All patients who come pay as per their warranties. This shows that RSUD Wates is committed to run a classless hospital in terms of cost with the same guarantee. Facilities obtained by patients in class I, II, and III alike, which distinguishes only the room only. Patients who should be in class III, then moved to class II get the same service all from doctors to drugs. So that there is no very basic difference for patients at Wates Hospital who have implemented a classless system.

In addition, the services provided by the hospital are easy and not complicated. Patients are given clear explanations and directions, so the patient is immediately given treatment by the hospital after completing all the requirements. Compared to previous years hospitals Wates who have implemented a classless system in terms of service can be considered satisfactory. In addition to this the response 
of the patients to the services provided by Wates Hospital was very good, so that the community or patients who had undergone treatment at the hospital recommended family, friends, or relatives to seek treatment at Wates Hospital, Kulonprogo. Improvement of facilities, especially in the addition of facilities such as air conditioning, fans, bed linen, pillows, etc. are very much expected by patients for the comfort of treatment.

\section{CONCLUSION}

Health services are basic services for the community that must be provided by the government. In carrying out health services the government must continue to improve the quality of service and innovation and contains a fair principle. Kulon Progo Regency government in realizing the excellent health service has made the policy of Classless Hospital in Kulon Progo, Yogyakarta Special Region. The innovation of health services aims to provide inpatient services to poor families easily and quality.

The health care policy through classless hospital is also a solution to the increasing public accessibility of health services, especially inpatient services. Through this policy, the community does not need to wait long to get inpatient services because there is already good service. The consequence of the health service policy is that the community responded positively by providing a good assessment of classless health services. What needs to be improved from the implementation of hospital policy without class is socialization 
25: directly or through the media both print and online needs to be improved; and it is necessary to improve the quality of health service facilities so that people are more comfortable.

\section{REFERENCES}

Huberman, dan Miles. (2014). Analisis Data Kualitatif. Jakarta: Universitas Indonesia.

Kuncoro, Wahyu, 2006. Studi Evaluasi Pelayanan Public Dan Kualitas Pelayanan Di Rumah Sakit Umum DR. Soetomo. Tesis.

Moleong, L. J. 2012. Metodologi Penelitian Kualitatif (Ed). Bandung: PT. Remaja Rosdakarya.

Nurharjadmo, Wahyu, 2008. Evaluasi Implementasi Kebijakan Pendidikan Sistem Ganda Di Sekolah Kejuruan, Spirit Public Vol. 4 No 2, Oktober.

Salim, Agus. 2006. Teori dan Paradigma Penelitian Sosial. Yogyakarta: Taira Wacana.

Susanti, Ulfah Aprilia, 2009. Akses Keluarga Miskin Terhadap Kualitas Pelayanan Kesehatan Di Rumah Sakit (Studi: Di Rumah Sakit Umum Patmasuri Yogyakarta), Skripsi.

http://indonesiaberinovasi.com/read/2015/03/300/bupati-kulonprogo-memberikan pelayanan-bagi-pasien-gakin-rsud-wates.

http://www.depkes.go.id/resources/download/profil/PROFIL_KAB_KOT A_2014/3401_DIY_Kab_Kulon_Progo_2014.pdf 